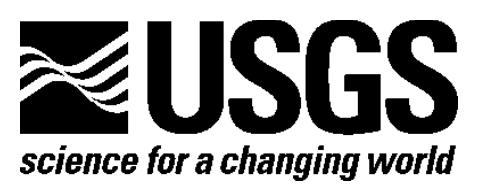

\title{
Karst in the United States: A Digital Map Compilation and Database
}

By David J. Weary and Daniel H. Doctor

Open-File Report 2014-1156

U.S. Department of the Interior

U.S. Geological Survey 


\section{U.S. Department of the Interior \\ SALLY JEWELL, Secretary}

\section{U.S. Geological Survey \\ Suzette M. Kimball, Acting Director}

U.S. Geological Survey, Reston, Virginia: 2014

For more information on the USGS-the Federal source for science about the Earth, its natural and living resources, natural hazards, and the environment-visit http://www.usgs.gov or call 1-888-ASK-USGS (1-888-275-8747).

For an overview of USGS information products, including maps, imagery, and publications, visit http://www.usgs.gov/pubprod/.

To order this and other USGS information products, visit http://store.usgs.gov/.

Any use of trade, firm, or product names is for descriptive purposes only and does not imply endorsement by the U.S. Government.

The database component of U.S. Geological Survey (USGS) Open-File Report 2014-1156 has been approved for release and publication by the USGS. Although this database has been subjected to rigorous review and is substantially complete, the USGS reserves the right to revise the data pursuant to further analysis and review. Furthermore, it is released on condition that neither the USGS nor the U.S. Government may be held liable for any damages resulting from its use.

Although this information product, for the most part, is in the public domain, it also may contain copyrighted materials as noted in the text. Permission to reproduce copyrighted items must be secured from the copyright owner.

Suggested citation:

Weary, D.J., and Doctor, D.H., 2014, Karst in the United States: A digital map compilation and database: U.S. Geological Survey Open-File Report 2014-1156, 23 p., http://dx.doi.org/10.3133/ofr20141156. 


\section{Contents}

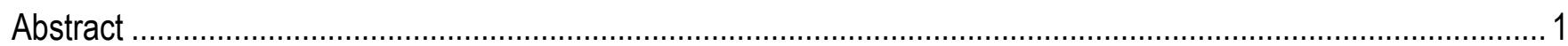

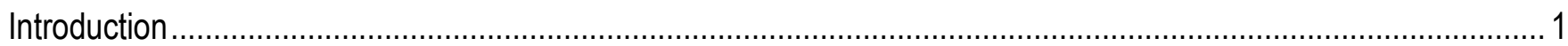

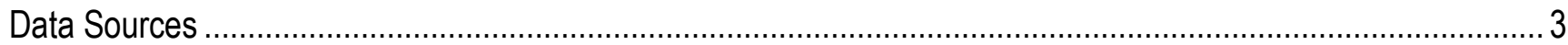

Purpose of these Data

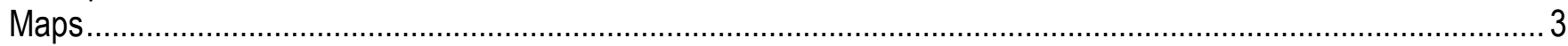

Map of Karst and Potential Karst Areas in Soluble Rocks in the Contiguous United States................................. 4

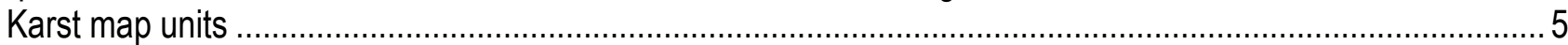

Map of Karst and Potential Karst Areas in Soluble Rocks in Alaska, Hawaii, Puerto Rico, and the U.S. Virgin Islands............................................................................................................................

Map of Areas Underlain by Evaporite Rocks at Various Depths up to 7,000 Feet Below the Land Surface in the Contiguous United States .........................................................................................................

Evaporite karst map units ..................................................................................................................

Map of Areas Having Potential for Development of Pseudokarst Features in the Contiguous United States........ 10 Map of Areas Having Potential for Development of Volcanic or Thermokarst Pseudokarst Features in Alaska

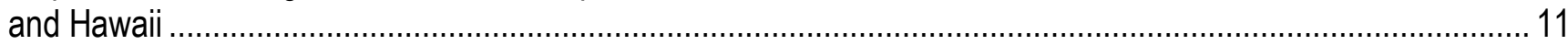

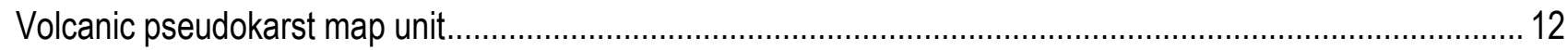

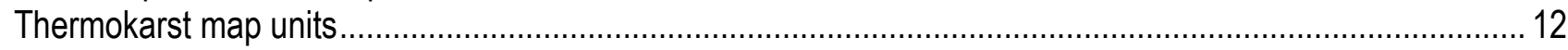

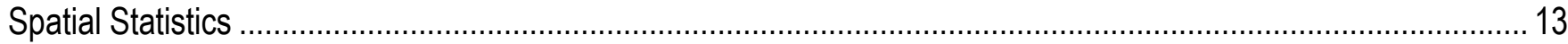

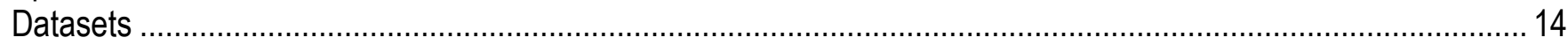

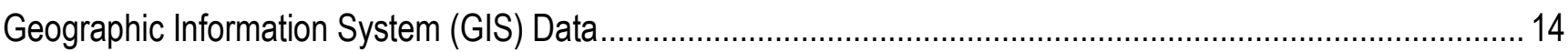

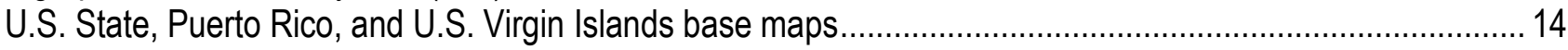

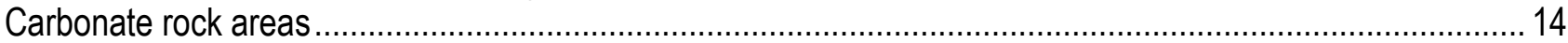

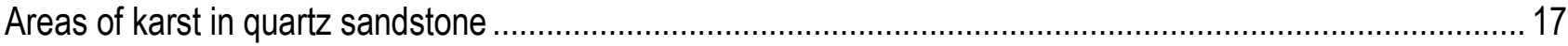

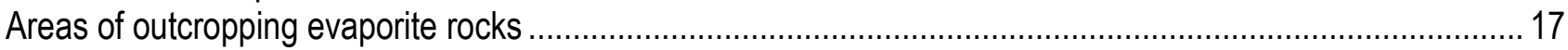

Areas of sedimentary basins containing thick deposits of evaporite rocks ................................................. 17

Area of greater extent of commonly occurring evaporite rocks in the subsurface............................................ 18

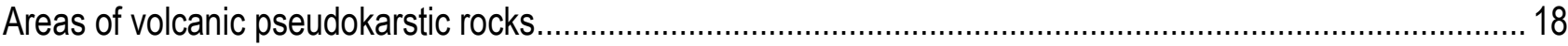

Areas of sedimentary pseudokarstic rocks, including areas prone to thermokarst in Alaska........................... 19

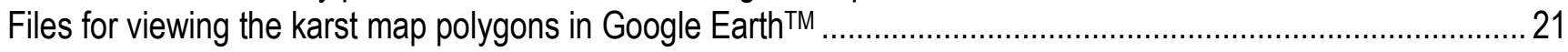

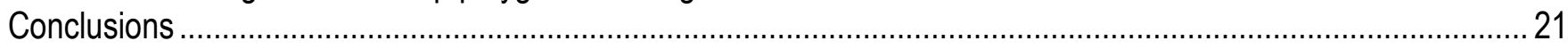

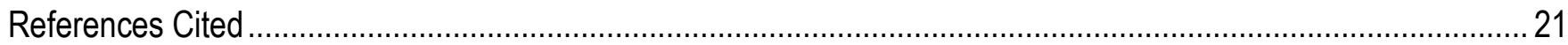

\section{Figures}

1. Karst and potential karst areas in soluble rocks in the contiguous United States.....................................5

2. Karst and potential karst areas in soluble rocks in Alaska, Hawaii, and Puerto Rico and the U.S. Virgin Islands ..........................................................................................................................

3. Areas underlain by evaporite rocks at various depths up to 7,000 feet below the land surface in the contiguous United States....................................................................................................... 10

4. Areas having potential for development of pseudokarst features in the contiguous United States.............. 11

5. Areas having potential for development of volcanic or thermokarst pseudokarst features in Alaska and Hawaii......

6. Chart showing proportion of the area of the 50 United States underlain by rocks and sediments having karst or pseudokarst features or a potential for them. 


\section{Conversion Factors}

Inch/Pound to SI

\begin{tabular}{lcl}
\hline & \multicolumn{1}{c}{ Multiply } & \multicolumn{1}{c}{ To obtain } \\
\hline inch (in.) & Length & \\
foot (ft) & 2.54 & centimeter (cm) \\
mile (mi) & 0.3048 & meter (m) \\
\hline
\end{tabular}

SI to Inch/Pound

\begin{tabular}{|c|c|c|}
\hline Multiply & By & To obtain \\
\hline \multicolumn{3}{|c|}{ Length } \\
\hline centimeter $(\mathrm{cm})$ & 0.3937 & inch (in.) \\
\hline meter $(\mathrm{m})$ & 3.281 & foot (ft) \\
\hline kilometer (km) & 0.6214 & mile (mi) \\
\hline
\end{tabular}




\title{
Karst in the United States: A Digital Map Compilation and Database
}

\author{
By David J. Weary and Daniel H. Doctor
}

\begin{abstract}
This report describes new digital maps delineating areas of the United States, including Puerto Rico and the U.S. Virgin Islands, having karst or the potential for development of karst and pseudokarst. These maps show areas underlain by soluble rocks and also by volcanic rocks, sedimentary deposits, and permafrost that have potential for karst or pseudokarst development. All 50 States contain rocks with potential for karst development, and about 18 percent of their area is underlain by soluble rocks having karst or the potential for development of karst features. The areas of soluble rocks shown are based primarily on selection from State geologic maps of rock units containing significant amounts of carbonate or evaporite minerals. Areas underlain by soluble rocks are further classified by general climate setting, degree of induration, and degree of exposure. Areas having potential for volcanic pseudokarst are those underlain chiefly by basaltic-flow rocks no older than Miocene in age. Areas with potential for pseudokarst features in sedimentary rocks are in relatively unconsolidated rocks from which pseudokarst features, such as piping caves, have been reported. Areas having potential for development of thermokarst features, mapped exclusively in Alaska, contain permafrost in relatively thick surficial deposits containing ground ice. This report includes a GIS database with links from the map unit polygons to online geologic unit descriptions.
\end{abstract}

\section{Introduction}

Numerous environmental and engineering problems arise in areas where natural geologic substrates are subject to solution and erosion, which can generate voids in the subsurface. Such areas are collectively known as karst. The term "karst" has traditionally been used to refer solely to regions of exposed soluble bedrock having an abundance of surface landforms, such as sinkholes, sinking streams, and springs, that reflect the presence of subsurface voids or caves (Ford and Williams, 2007). However, during the last few decades a distinction has been drawn between karst features that reflect surficial (epigenic) solutional processes and karst features that reflect deep-seated (hypogenic) solutional processes, both of which result in bedrock voids (Palmer, 1991). Consequently, usage of the term "karst" has broadened, as recognition of karst features existing deep in the subsurface in numerous environments has gained greater attention (Klimchouk, 2007).

The development of karst is primarily dependent on the presence of soluble rocks; therefore, efforts to map karst distribution have normally taken a geology-based approach, effectively delineating areas having potential for karst development by compiling areas of soluble rocks from geologic maps (for example, see Williams and Ford, 2006). In this report, we have taken a similar geology-based approach by compiling regions of known and potential karst in the United States using the latest, most 
detailed digital geologic map information. While this approach is representative of karst potential, a complex interaction of many factors determines the formation, localization, and intensity of karst feature development. These include the bedrock geology (rock type and structure), tectonics, climate, sedimentary cover, vegetation, local hydrologic conditions, and time. However, even very sparse karst features evident at the land surface can indicate important groundwater flow processes that are characteristic of karst in the broader subsurface. Thus we have included all areas containing soluble bedrock lithologies as potentially hosting karst features.

This report was produced to illustrate the extent and varieties of karst and potential karst across the United States, including areas having potential for features analogous to karst that arise from processes other than rock solution, termed pseudokarst (Halliday, 2007). Potential pseudokarst landscapes include areas underlain by geologic materials susceptible to the formation of voids produced by lava flows, by erosion of fine-grained sediments by means of piping (stoping), and by melting of permafrost. Examples include (1) lava tubes in relatively young (Miocene and younger) volcanic flow rocks (primarily basalts) sometimes referred to as vulcanokarst (U.S. Environmental Protection Agency, 2002), (2) piping features within unconsolidated sediments in semiarid to arid regions, and (3) areas of piping in sediments affected by intermittently or progressively thawing permafrost in Alaska.

Pseudokarst landscapes in lava tube areas and in permafrost areas are also known as thermokarst (Sweeting, 1973). In addition, large integrated groundwater flow systems, some of which resurge at large springs, occur in some areas of layered volcanic rocks in the western United States. These include the Columbia Plateau aquifer system in Oregon and Washington and the Snake River Plain aquifer system in Idaho.

The geographic extent of this report includes the 50 States, Puerto Rico, and the U.S. Virgin Islands. Puerto Rico and the U.S. Virgin Islands were included because of the large size of Puerto Rico, availability of digital karst data (Alemán González, 2010), and geographic proximity to the contiguous United States. There are significant karst and pseudokarst terrains in the other, more distant U.S. territories not included in this report. These include areas of Guam, the Commonwealth of the Northern Mariana Islands, American Samoa, and the U.S. Minor Outlying Islands (several Pacific islands and Navassa Island in the Caribbean).

Several thematic maps are presented that show (1) karst and potential karst areas in soluble rocks (for example, limestone, dolomite, gypsum, anhydrite, halite, and so forth) exposed at the surface or buried at shallow depths in the contiguous United States (fig. 1); (2) karst and potential karst areas in soluble rocks (for example, limestone and dolomite) in Alaska, Hawaii, Puerto Rico, and the U.S. Virgin Islands (fig. 2); (3) areas underlain by evaporate rocks at various depths up to 7,000 feet (ft) below the land surface in the contiguous United States (fig. 3); (4) areas having potential for development of pseudokarst features in the contiguous United States (fig. 4); and (5) areas having potential for development of volcanic or thermokarst pseudokarst features in Alaska and Hawaii (fig. 5). The maps in this report are intended to supersede the National Atlas map "Engineering aspects of karst" by Davies and others (1984).

The extent of outcrop of soluble rocks provides a good first approximation of the distribution of karst and potential karst areas, particularly in parts of the United States with a humid climate. Criteria for further refinement of the karst map units in this report include (1) climate of regions based on annual precipitation and ecoregion designation, (2) depth of burial of the soluble rocks and nature of the overlying sediments, and (3) degree of consolidation of the lithostratigraphic unit.

Ecoregions are areas having similar climate, physiography, geology, soils, and other natural features (U.S. Environmental Protection Agency, 2013). Level III Ecoregions approximate the size and extent of many of the well-known karst regions in the United States. The extents of the Level III 
Ecoregions provide a spatial framework for classifying karst terrains into areas affected by similar climatic and physiographic conditions at regional scales.

The geographic information system (GIS) data that accompany this report represent karst areas as spatially registered polygons containing multiple attributes that allow the user to perform selection and analysis on the data. Certain attributes also allow linking back to the original lithostratigraphic unit descriptions and ecoregion descriptions. Labels for these attributes are as follows: KARST_TYPE, Climate, Induration, Exposure, ROCKTYPE1, ROCKTYPE2, ROCKTYPE3, UNIT_NAME, UNIT_AGE, State, UNIT_LINK, URL, NA_L3NAME, and NA_L3CODE. Refer to the Datasets section of this report that describes the GIS data in greater detail and that provides more information on these attributes.

\section{Data Sources}

Most of the spatial data compiled during this project originated as lithologic map units on geologic maps produced by State geological surveys. Versions of the original source maps are available for purchase or download from the respective State geological surveys. Much of the digital map data for this project was compiled from a series of integrated geologic map databases for the United States produced by the U.S. Geological Survey (USGS) Mineral Resources Program (see http://mrdata.usgs.gov/geology/state/, accessed May 16, 2014). Use of the USGS digital geologic data provided a consistent data structure within which a derivative database of areas having potential for karst could be constructed. Edits, deletions, and additions to this database were made based on (1) comparison to other published karst maps (principally Davies and others, 1984; Veni, 2000); (2) comments and contributions by other cave and karst researchers having local knowledge of particular areas, and assisted by the comprehensive compilation in Palmer and Palmer (2009); and (3) the personal knowledge of the authors. Further characterization of the karst areas was also accomplished via overlay analyses with other data, including distribution of glacially derived sediments (Soller and others, 2012), permanently frozen ground (Brown and others, 2002), and Level III Ecoregions (U.S. Environmental Protection Agency, 2013).

\section{Purpose of these Data}

These data were compiled to delineate the distribution of karst and potential karst and pseudokarst areas of the United States. The data in this report are preliminary and there is an expectation of upgrade in content, quality, and resolution in future versions. The data are released as an Open-File Report to expedite transfer of this information to various users across the United States. These data were compiled from multiple sources at various spatial resolutions. They are intended for use as guidance in determining the distribution of areas of potential karst at national, State, and regional scales. Because of differences in projection and scale of the various geologic datasets, spatial errors and location inconsistencies are particularly noticeable along some State boundaries, particularly coastlines and riparian borders. These data should not be used to define boundaries for site-specific applications or for legal purposes.

\section{Maps}

The maps shown in figures 1 to 5 were generated from GIS data having various originalresolution scales. The resolution of the geologic data ranges from 1:24,000 to 1:500,000. The graphic files provided are designed for display at 1:6,000,000 scale for the contiguous United States and Alaska, 
and 1:3,000,000 scale for Hawaii, Puerto Rico, and the U.S. Virgin Islands. They will print at these scales at 100 percent resolution. The geographic data for all of these maps are in Albers Equal-Area projection using the North American Datum of 1983.

\section{Map of Karst and Potential Karst Areas in Soluble Rocks in the Contiguous United States}

The distribution of karst and potential karst areas in soluble rocks in the contiguous United States is shown in figure 1. Distribution of areas of mature surface karst in the contiguous United States is primarily dependent on the presence of soluble rocks at or near the land surface and mean annual precipitation above approximately 30 inches (in.) (76 centimeters $(\mathrm{cm}))$. In the humid parts of the United States, most karst features such as caves and sinkholes (dolines) occur in carbonate (limestone and dolomite) rocks; evaporite rocks are rarely found at or near the surface in these humid areas. The eastern United States and a large part of the Pacific coastal zone are considered to be humid. Locally, areas of the Rocky Mountains and the Sierra Nevada are also classified in this report as humid regions, with higher effective precipitation amounts mostly due to orogenic effects. All areas of Alaska, Hawaii, Puerto Rico and the U.S. Virgin Islands are considered humid at the resolution of this study. In the semi-arid and arid regions of the western United States, carbonates are more resistant to erosion due to lower precipitation, and most prominent karst features occur in the more soluble evaporite rocks that can exist at or near the surface in those environments. Karst features created by hypogenic processes tend to be better preserved in arid and semi-arid areas because these features are less likely to be modified by epigenic processes in drier climates (Palmer, 2000; Auler and Smart, 2003).

The potentially karstic areas shown in figure 1 are grouped by areas of humid climate and areas of dry (semi-arid to arid) climate. In addition to carbonate and evaporite rocks, an area of quartz sandstone in Minnesota with documented solution karst is also shown (Shade, 2002). Other areas of anomalous solution, in what are normally considered insoluble rocks, may exist elsewhere in the United States and are yet to be documented.

For this report, the boundaries between dry and humid regions were delineated by comparing the average annual precipitation map for the years 1961 through 1990 with descriptions of North American Level III Ecoregions (Daly and Taylor, 2000; U.S. Environmental Protection Agency, 2013). The humid versus dry climate karst boundaries defined herein are coincident with the Level III Ecoregion boundaries and they approximate the 30 -in. $(76-\mathrm{cm})$-per-year annual average precipitation isohyet (Daly and Taylor, 2000). These boundaries, although shown as hard lines in figures 1 and 2, are actually diffuse and approximate. Because the boundaries are forced to coincide with those of the ecoregions, karst in some marginal areas may be inaccurately portrayed at finer scales. In addition, some relatively dry areas of the country are known to receive precipitation concentrated in particular seasons, resulting in effective precipitation and denudation rivaling or exceeding that in some areas classified as humid. One example is the Kings Canyon area, California, which averages less than 30 inches of precipitation per year, but receives most of it from January to mid-May.

The southern part of the north-south-trending boundary separating the humid eastern from the dry western areas of the United States in figure 1 also approximates the southern part of the 32.5-in. (82.6-cm)-per-year annual average precipitation isohyet used by Epstein and Johnson (2003) to separate karst regions. There is some divergence of the humid and dry region boundaries from the principal 30in. precipitation line at both north and south latitudes, as the effective regional humidity is also a function of the regional evapotranspiration rate, which itself is affected by temperature. Occurrence of soluble rocks in either humid or dry regions is reflected in the map unit classifications and colors in figure 1 and in the database. 
Effects of late Cenozoic glaciations have a profound influence on the development and preservation of karst features in the northern and eastern parts of the contiguous United States. The line approximating the greatest extent of the last glaciation is shown in figure 1, and the thickness of glacially derived sediments overlying areas of soluble rocks is also integrated into the classification of map units. Glacial data used in this report are derived from Soller and others (2012).

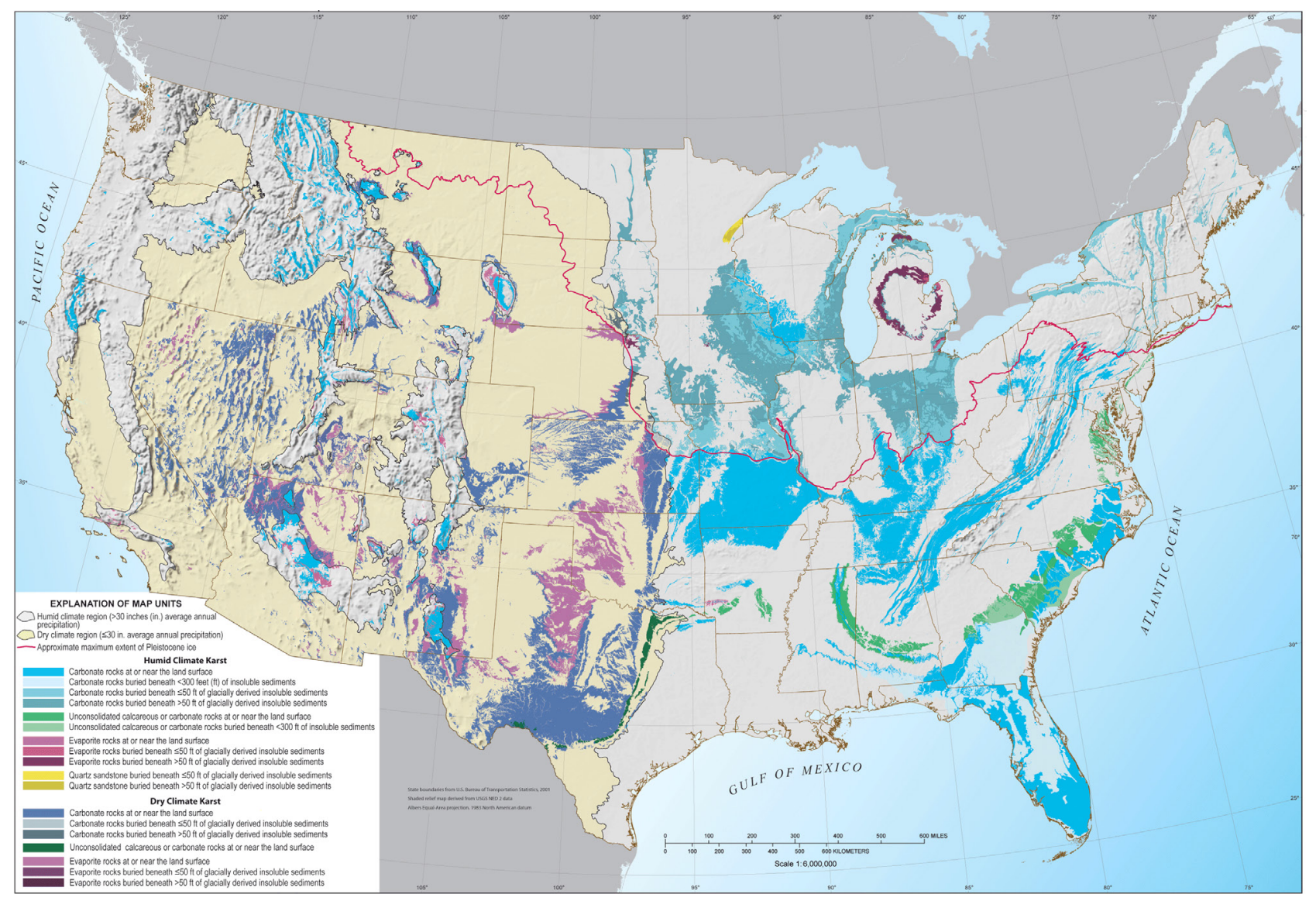

Figure 1. Karst and potential karst areas in soluble rocks in the contiguous United States.

\section{Karst map units}

\section{Carbonate rocks at or near the land surface}

These areas are underlain directly by carbonate bedrock, including unconsolidated calcareous sediments in the Atlantic and Gulf Coastal Plains, or by a veneer of sediments covering carbonate bedrock or sediments. In humid regions these units are typically karstified and contain varying densities of sinkholes, caves, and other karst features. Surface karst features such as solutional karren, solutionally enlarged fractures or pits in outcrops, and bedrock pinnacles surrounded by regolith comprise an epikarst that may be well developed locally, with relief in excess of $30 \mathrm{ft}(9 \mathrm{~m})$ in some areas. In semi-arid and arid regions, these rocks may exhibit very few large karst features, and sinkholes become rare. Rather, small-scale features such as karren become the most common types. It can be argued that many of these arid carbonate areas are not karstic under present climatic conditions; however, a number of deep-seated solutional karst and (or) paleokarst features may be exposed as a result of tectonic uplift and erosion (Palmer and Palmer, 2011). 


\section{Carbonate rocks buried beneath $<300$ feet of insoluble sediments}

These are areas where carbonate rocks are known to occur in the relatively shallow subsurface and where voids are known to propagate up through the cover of overlying sediment. In this study, only areas in the humid southeastern United States southern Atlantic and Gulf Coastal Plains and the Florida peninsula are classified as such. Other areas of the country, such as the Ozark Plateaus, also have similar mantled landscapes, but are not differentiated as such in this report.

Carbonate rocks buried beneath $\leq 50$ feet of glacially derived insoluble sediments

These are areas of carbonate rocks overlain by thin deposits of glacially derived sediments. Units were identified for this classification by overlaying data from the map of Soller and others (2012) on a map of carbonate bedrock units. Cover-collapse sinkholes are common in some of these areas where karst is overlain by loess or other cohesive unconsolidated deposits.

\section{Carbonate rocks buried beneath $>50$ feet of glacially derived insoluble sediments}

These are areas in the northeastern and Midwestern parts of the conterminous United States where carbonate rocks lie beneath relatively thick deposits of glacially derived sediments such as stratified drift and till. The vast majority of these areas occur in the humid region of the eastern United States. Because of the overlying sedimentary cover, karst features are rare at the surface. However, these areas may be vulnerable to groundwater contamination, particularly where high-permeability sediments overlie buried carbonates.

\section{Unconsolidated calcareous or carbonate rocks at or near the land surface}

These are areas underlain by unconsolidated to poorly consolidated calcareous or carbonate rocks at or very near the surface. They occur chiefly as Mesozoic and Cenozoic marine sediments along the Atlantic and Gulf Coastal Plains and in both humid and semi-arid climates. Rock types range from chalks to marls and other units particularly rich in calcareous fossil shell material. These units are generally not prone to formation of caves or subterranean voids; however, local high-permeability zones with conduits may develop along contacts with less soluble units such as shales and sandstones. The most common karst features in these units are subtle shallow depressions (sinkholes) produced by localized dissolution of the carbonate material.

Unconsolidated calcareous or carbonate rocks buried beneath $<300$ feet of insoluble sediments

These are areas of calcareous sediment or poorly consolidated carbonate rocks buried beneath up to $300 \mathrm{ft}$ of insoluble sediments. Ground subsidence or sinkholes may rarely occur in these areas.

\section{Evaporite rocks at or near the land surface}

These are areas of lithologic units consisting of or containing evaporite rocks (principally gypsum, anhydrite, and halite) exposed at or near the surface. Most outcrops occur in the western part of the contiguous United States in semi-arid to arid climates. Areas of this unit in Michigan comprise Paleozoic strata bearing interbedded evaporite mineral deposits. Solution cavities, caves, and sinkholes are the primary karst-related engineering hazards in the semi-arid and arid regions of the country. 
Evaporite rocks buried beneath $\leq 50$ feet of glacially derived insoluble sediments

These are areas of lithologic units consisting of or containing evaporite rocks (principally gypsum, anhydrite, and halite) buried beneath $\leq 50 \mathrm{ft}$ of glacially derived sediments. Most of these occurrences are in the Michigan basin.

Evaporite rocks buried beneath $>50$ feet of glacially derived insoluble sediments

These are areas of lithologic units consisting of or containing evaporite rocks (principally gypsum, anhydrite, and halite) buried beneath $>50 \mathrm{ft}$ of glacially derived sediments. Most of these occurrences are in the Michigan basin.

Quartz sandstone buried beneath $\leq 50$ feet of glacially derived insoluble sediments

Karst features including sinkholes, stream sinks, springs, and short caves have been documented in an area of quartz sandstone (Hinckley Sandstone) in Pine County, east-central Minnesota (Shade, 2002). Most of this area is mantled with deposits of glacially derived sediments of various thickness.

Quartz sandstone buried beneath $>50$ feet of glacially derived insoluble sediments

These are areas of quartz sandstone buried beneath relatively thick deposits of glacially derived insoluble sediments. Expression of karst features at the ground surface is less likely in these areas.

\section{Map of Karst and Potential Karst Areas in Soluble Rocks in Alaska, Hawaii, Puerto Rico, and the U.S. Virgin Islands}

The distribution of karst and potential karst areas of soluble rocks in Alaska, Hawaii, Puerto Rico, and the U.S. Virgin Islands is shown in figure 2. All of these areas have relatively humid climates, so evaporite rocks generally do not occur at or near the land surface. Areas of carbonate rocks occurring at or near the surface are shown as a single map unit in figure 2 . 


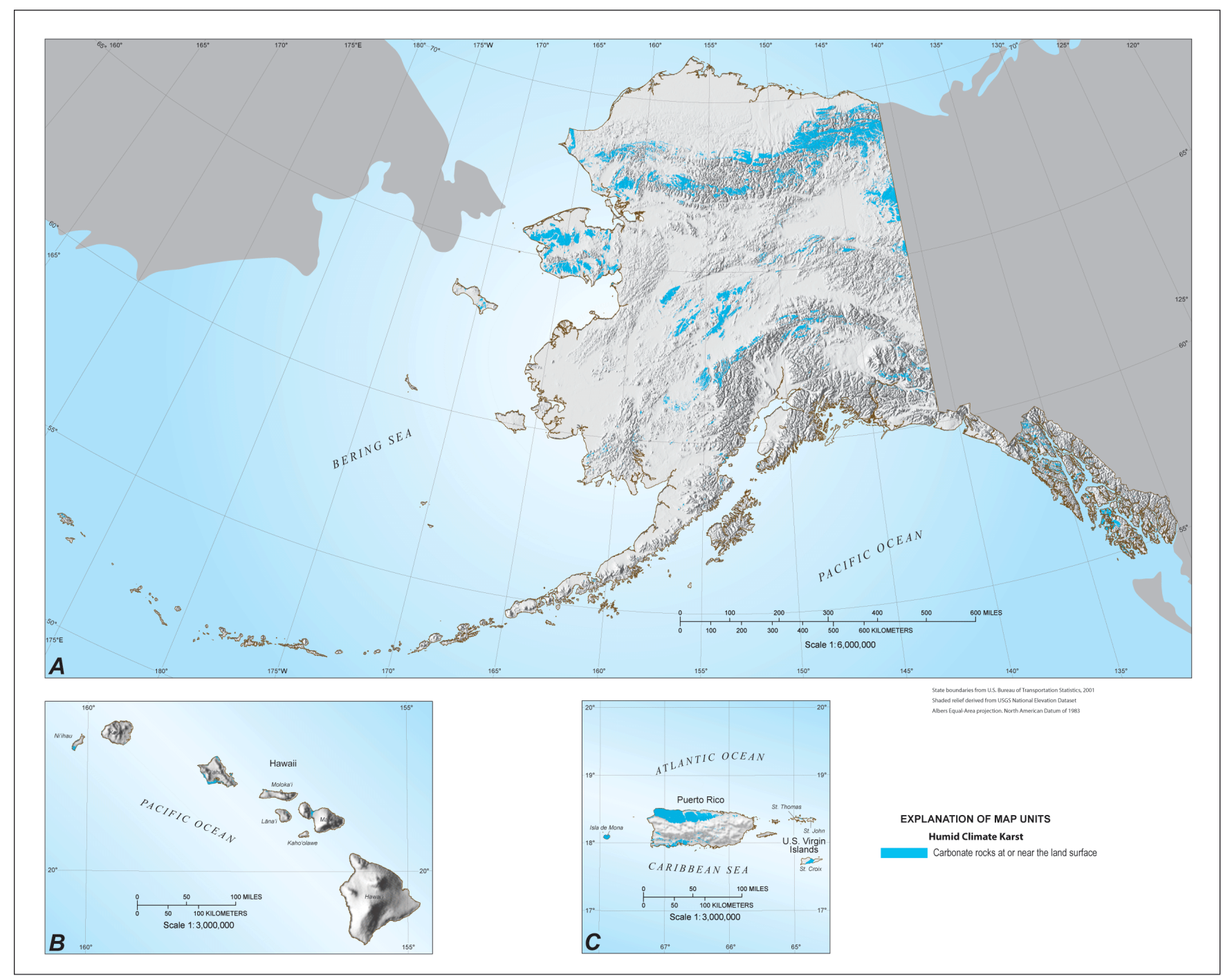

Figure 2. Karst and potential karst areas in soluble rocks in $A$, Alaska; $B$, Hawaii; and $C$, Puerto Rico and the U.S. Virgin Islands.

Carbonate areas found in the temperate rainforests of southeastern Alaska constitute the best developed and most well-known karst in that State. Little is known about other karst areas to the north and west, but carbonate rocks are abundant.

Karst in Hawaii occurs in relatively young, island-fringing limestones. Small areas of these limestones occur on all of the major islands of Hawaii with the exceptions of Kaho olawe and Hawai' $i$.

The U.S. Commonwealth of Puerto Rico has areas of well-developed karst in both Mesozoic and Cenozoic limestones. Most of the larger karst features, including very large and abundant sinkholes, are in the northwestern and north-central parts of the island. The large Puerto Rican Mona Island (Isla de Mona) to the west of the main island is almost 100 percent karst.

The U.S. Virgin Islands contain areas of Cenozoic limestone and dolomite bearing karst features. These areas occur in the central part of the island of St. Croix and along the northern parts of the islands of St. Thomas and St. John. 


\section{Map of Areas Underlain by Evaporite Rocks at Various Depths up to 7,000 Feet Below the Land Surface in the Contiguous United States}

In addition to showing areas of outcropping and near-surface evaporite rocks in the contiguous United States, figure 3 shows the extent of subsurface evaporite basins and the greater extent of commonly occurring evaporite rocks in the subsurface. The evaporite basins contain soluble rocks buried to depths of as much as 7,000 ft, but generally much less. Because of the physical properties and very high solubility of evaporite rocks, human activities such as fluid injection, or the occurrence of leakage from well casings, can induce the formation of large solution voids. Collapses of these voids are known to propagate up to the surface from depths of more than $1,000 \mathrm{ft}$.

Evaporite karst map units

As in figure 1, figure 3 shows various areas underlain by evaporite rocks, either exposed at the land surface or covered by various thicknesses of glacially derived sediments. Humid-climate and dryclimate areas, and the greatest extent of the last glaciation, are also shown.

Greater extent of commonly occurring evaporite rocks in the subsurface

This is a large area of the western part of the contiguous United States where stratified evaporite rocks commonly occur in the subsurface, in intrabasinal areas, or other areas peripheral to the extent of defined evaporite basins. The evaporite rocks found in this area are mainly gypsum and anhydrite. The area of greater extent was modified from Johnson (2007).

Evaporite basins

The extent of the evaporite basins is derived in part from information in Dunrud and Nevins (1981) and Johnson (2007). 


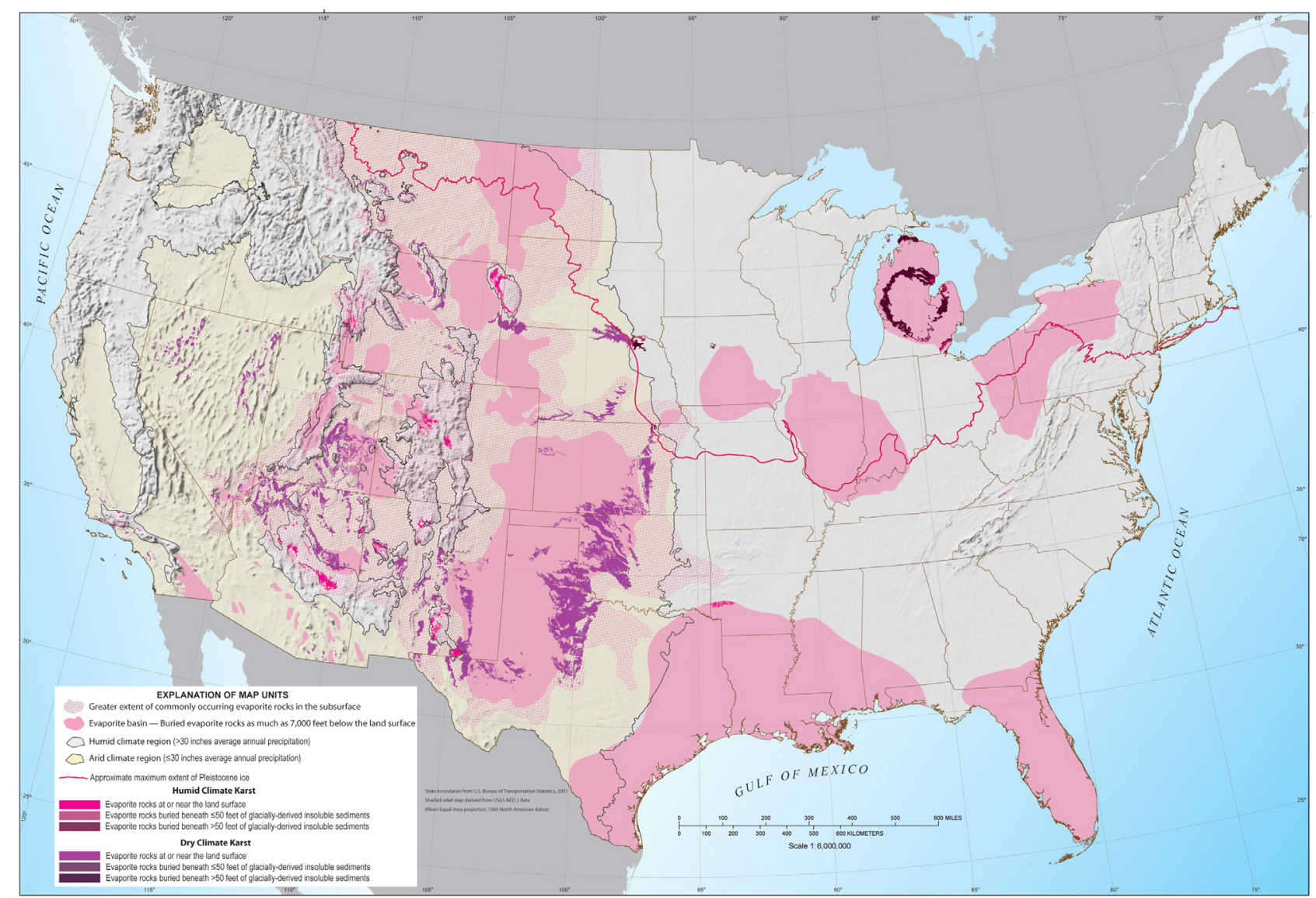

Figure 3. Areas underlain by evaporite rocks at various depths up to 7,000 feet below the land surface in the contiguous United States.

\section{Map of Areas Having Potential for Development of Pseudokarst Features in the Contiguous United States}

Two different units are portrayed on the map of pseudokarst-potential areas in the contiguous United States (fig. 4). They are (1) areas of poorly consolidated sedimentary rocks known, at least locally, to contain piping features (tubes, caves, and subsidence features); and (2) areas of volcanic rock that may contain lava tubes and (or) layered volcanic rocks with integrated fast groundwater flow systems. Lava tube terrains are sometimes termed vulcanokarst (U.S. Environmental Protection Agency, 2002). 


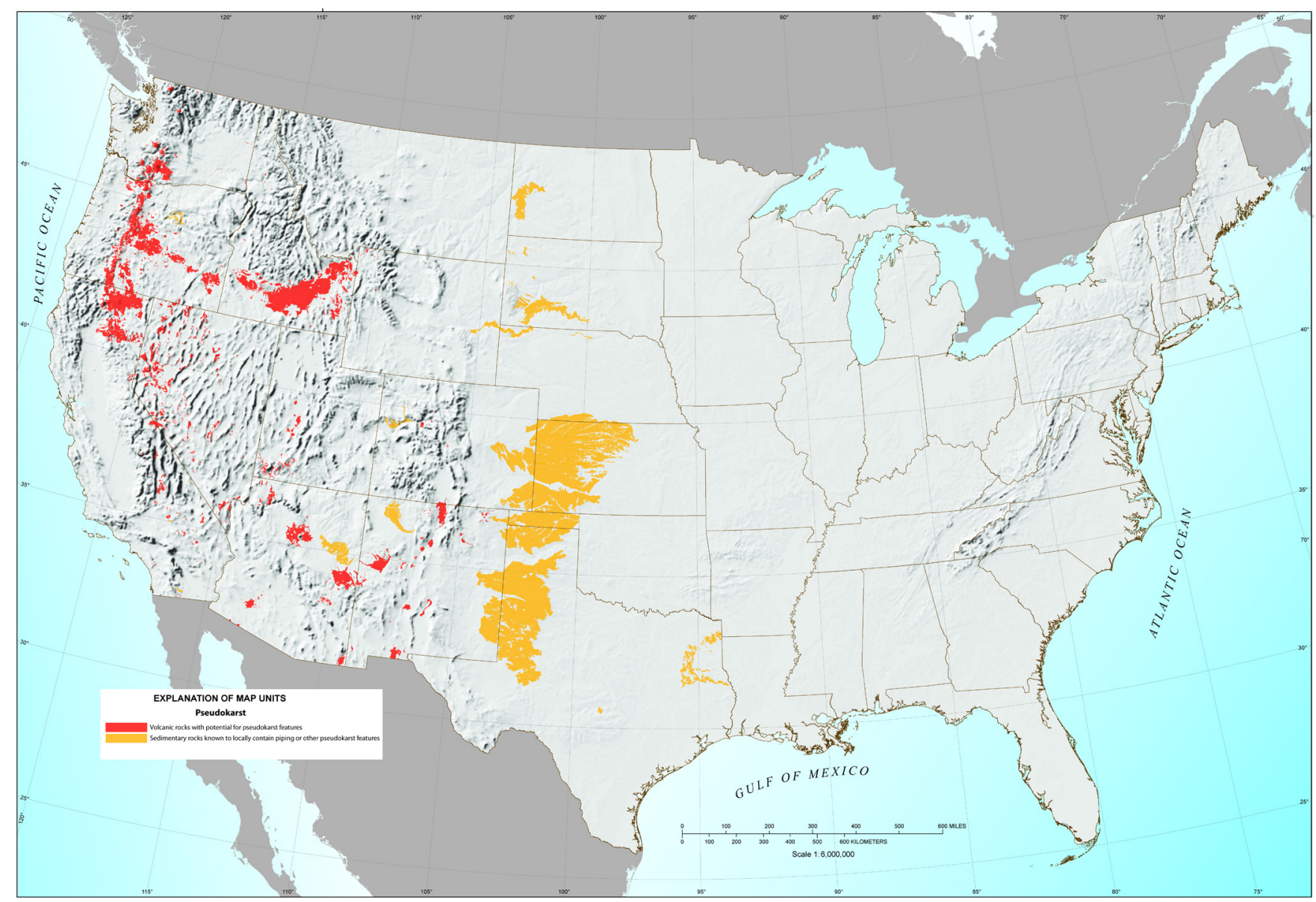

Figure 4. Areas having potential for development of pseudokarst features in the contiguous United States.

Most of the areas with piping potential occur in fine-grained sedimentary rocks in the High Plains, in the Badlands of North and South Dakota, and in western Colorado, east Texas, northwestern New Mexico, northeastern Arizona, southern Utah, southern California, and north-central Oregon. The areas shown are those known locally to contain pseudokarst features.

\section{Map of Areas Having Potential for Development of Volcanic or Thermokarst Pseudokarst Features in Alaska and Hawaii}

Because of their relatively recent and ongoing volcanism, both Alaska and Hawaii contain abundant, relatively young (Miocene age or younger) extrusive igneous rocks that may contain lava tubes and (or) layered volcanic rocks with integrated fast groundwater flow systems. (fig. $5 A, B$ ). Lava tubes form most readily and extensively in low-viscosity lava flows, usually of basaltic composition. Lava tubes are relatively short-lived geologic features because (1) they are either filled, post-formation, by succeeding eruptive lavas, or (2) since they are near the surface, they are susceptible to erosion and collapse of the overlying rocks. Lava tubes generally are not found in rocks older than Miocene age, and this age was used as a cutoff for selecting volcanic flow units for this map.

The cold climate of Alaska has resulted in extensive regions of permafrost, or frozen ground (Brown and others, 2002) (fig. 5A). As the climate warms, however, these areas are experiencing melting, resulting in landforms and hydrologic conditions that are analogous to karst terrains, such as sinkholes and sinking streams. Because this phenomenon is related to melting of ice rather than to 
solution of bedrock, these permafrost features are considered a category of pseudokarst (Halliday, 2007) and are termed thermokarst (Sweeting, 1973, p. 308).

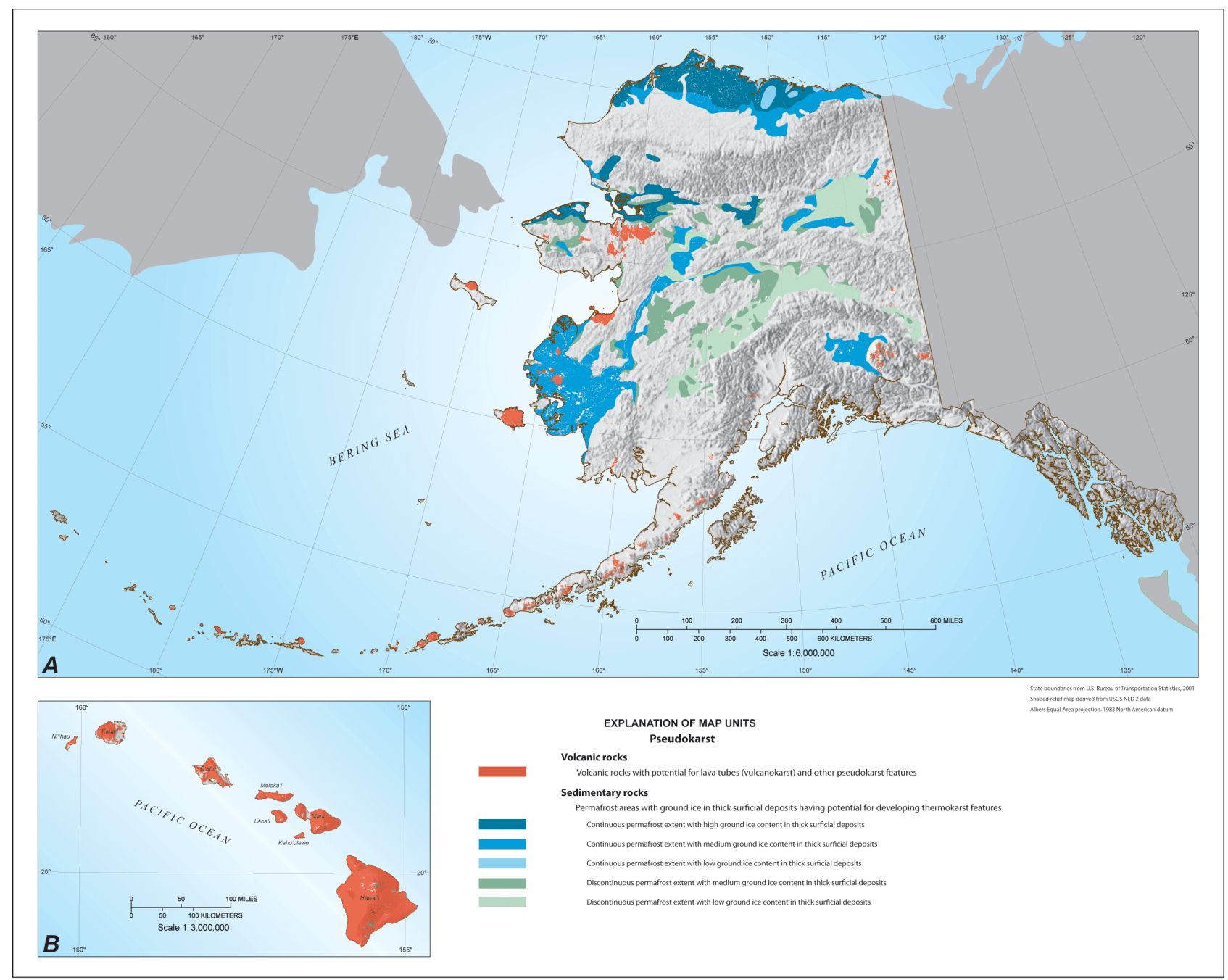

Figure 5. Areas having potential for development of volcanic or thermokarst pseudokarst features in A, Alaska; $B$, Hawaii.

\section{Volcanic pseudokarst map unit}

Volcanic rocks having potential for pseudokarst features

These are areas of volcanic rock that may contain lava tubes and (or) layered volcanic rocks with integrated fast groundwater flow systems.

\section{Thermokarst map units}

Permafrost areas in Alaska having potential for thermokarst features based upon the extent of relatively thick surficial deposits containing ground ice are listed below. The generation of these units is described in more detail in the section entitled Geographic Information System (GIS) Data. These units are (1) Continuous permafrost extent with high ground-ice content in thick surficial 
deposits; (2) Continuous permafrost extent with medium ground-ice content in thick surficial deposits; (3) Continuous permafrost extent with low ground-ice content in thick surficial deposits; (4) Discontinuous permafrost extent with medium ground-ice content in thick surficial deposits; and (5) Discontinuous permafrost extent with low ground-ice content in thick surficial deposits.

\section{Spatial Statistics}

Simple spatial statistics were calculated from the area of the United States, in percent, underlain by the areas of karst and pseudokarst defined in this report. Because the other U.S. territories were not included in this report, statistics for karst areas of Puerto Rico and the U.S. Virgin Islands were not included in these calculations. The results are presented in figure 6. In summary, about 25 percent of the United States is underlain by rocks and sediments of all types having karst or pseudokarst features or a potential for them. About 18 percent of the country is underlain by soluble rocks; within this category, 16 percent of the nation is composed of carbonate rocks and 2 percent is evaporite rocks. The area of the country underlain by basins where evaporite rocks may be encountered by deep drilling (up to 7,000 ft) was not included in the calculations for figure 6 because, technically, these rocks at depth are not karst. Moreover, these values underestimate the area of the United States underlain by karst aquifers, a major source of potable water for the nation. About 2 percent of the United States is underlain by sedimentary rocks prone to development of pseudokarst features primarily by piping. Approximately 3.6 percent of the country, restricted to Alaska, is underlain by permafrost areas having potential for thermokarst. Areas in the western part of the contiguous United States and in Alaska and Hawaii are underlain by volcanic rocks having potential for lava tubes, and represent about 1.5 percent of the total area of the nation.

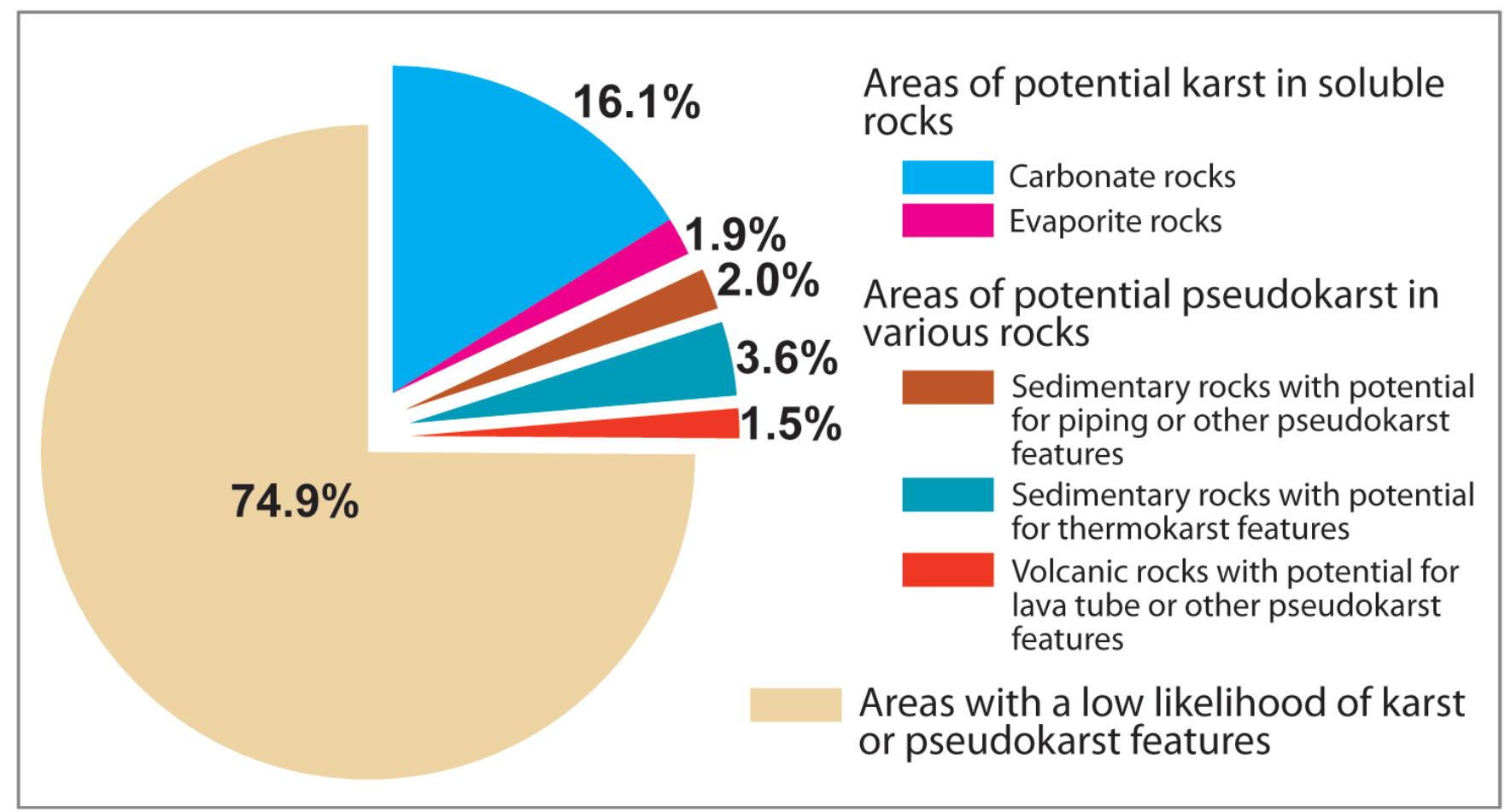

Figure 6. Chart showing proportion of the area of the 50 United States underlain by rocks and sediments having karst or pseudokarst features or a potential for them. 


\section{Datasets}

Polygon data for this report are available as both GIS data and as Keyhole Markup Language (KML) files that can be viewed within a virtual globe such as Google Earth $^{\mathrm{TM}}$.

\section{Geographic Information System (GIS) Data}

All GIS datasets included in this report are polygons in ESRI shapefile format. A metadata file to describe each shapefile is also available for download. All polygons representing the extent of potential karst and pseudokarst areas in the datasets covering the contiguous (lower 48) United States contain uniform identification and classification information in a single table structure. This data structure, with several deletions and additions, follows that used by the USGS Mineral Resources Program series of integrated geologic map databases for the United States (http://mrdata.usgs.gov/geology/state/). All polygon boundaries are split in coincidence with the provided State boundaries. The polygons also are split at the boundaries of North American Level III Ecoregions.

Available source data for Alaska, Hawaii, Puerto Rico, and the U.S. Virgin Islands were structured differently from the source data for the lower 48 States, and tabular data for those files differ as noted below. Although data are available for karst areas of Puerto Rico and the U.S. Virgin Islands, they were not included in the calculations to produce the information shown in figure 6 , since other U.S. territories were excluded.

\section{U.S. State, Puerto Rico, and U.S. Virgin Islands base maps}

Shapefiles containing polygons delineating the boundaries of the 50 United States, Puerto Rico, and the U.S. Virgin Islands are provided for download in this report.

\section{Carbonate rock areas}

Five separate shapefiles are provided for karst areas in carbonate rocks. They are (1) carbonate rocks in the contiguous United States, (2) carbonate rocks in Alaska, (3) carbonate rocks in Hawaii, (4) carbonate rocks in Puerto Rico, and (5) carbonate rocks in the U.S. Virgin Islands.

Attributes of the polygons

KARST_TYPE

The KARST_TYPE attribute is a text value corresponding to categories in the explanation of map units in figure 1. These categories are derived from a combination of the "Climate," "Induration," and "Exposure" values for each polygon. All the carbonate karst data tables contain this item.

\section{CLIMATE}

This attribute contains a code word indicating the amount of effective precipitation within each karst polygon. Terms used are "humid," indicating greater than about 30 in. $(76 \mathrm{~cm})$ mean annual precipitation, and "dry," indicating less than about 30 in. mean annual effective precipitation. All the carbonate karst data tables contain this item. 


\section{INDURATION}

The value of this attribute indicates a general sense of degree of induration of the lithologic unit. Terms used are "consolidated" and "unconsolidated." This attribute is used only in the two shapefiles for carbonate rocks in the contiguous United States. All the carbonate karst data tables contain this item.

\section{EXPOSURE}

This attribute contains a code for the general nature of the exposure of the lithostratigraphic unit. Codes include: E, B1, B2, and B3. Code E indicates exposure at or near the Earth's surface. Code B1 indicates burial of the unit beneath as much as $300 \mathrm{ft}(91 \mathrm{~m})$ of insoluble, and younger, coastal plain sediments. Code B2 indicates that the unit is buried by more than $50 \mathrm{ft}(15.2 \mathrm{~m})$ of glacially derived insoluble sediment. Code B3 indicates that the unit is in a glaciated area and may be covered by less than $50 \mathrm{ft}(15.2 \mathrm{~m})$ of glacial sediment, particularly loess. This attribute is not included in the data for volcanic rocks or for areas of sedimentary rocks having potential for pseudokarst features. All the carbonate karst data tables contain this item.

ROCKTYPE1

First lithologic descriptor from the original State geologic map. It is assumed in most cases that this is the most abundant lithology within a heterolithic rock unit. The table for Hawaii contains a single ROCKTYPE item. Tables for Puerto Rico and the U.S. Virgin Islands contain an analogous LITHOLOGY item.

\section{ROCKTYPE2}

Second lithologic descriptor from the original State geologic map. Tables for Hawaii, Puerto Rico, and the U.S. Virgin Islands do not contain this attribute.

\section{ROCKTYPE3}

Third lithologic descriptor from the original State geologic map. It is assumed in most cases that this is the least abundant lithology within a heterolithic rock unit. Tables for Hawaii, Puerto Rico, and the U.S. Virgin Islands do not contain this attribute.

\section{UNIT_NAME}

Name of the rock unit provided from the original State geologic map. Names are dependent on the usage within each State and may change across State boundaries. All the carbonate karst data tables contain this item. The data table for Puerto Rico also has a MAP_UNIT item that contains an abbreviation used in the source map (Alemán González, 2010). The table for Alaska also has an additional LABEL item containing abbreviations of the geologic map units from the source data.

UNIT_AGE

A text description of the age or age range of the lithostratigraphic unit. The table for Hawaii contains an analogous AGE_RANGE field. The tables for carbonates in Alaska, Puerto Rico, and the U.S. Virgin Islands do not contain this item. 
Standard U.S. Postal Service abbreviation for the State in which the polygon lies. Because they are separate datasets, the tables for Hawaii, Puerto Rico, and the U.S. Virgin Islands do not contain this attribute.

UNIT_LINK

The UNIT_LINK attribute is a code based on the map symbol abbreviation used in the original State geologic map depiction of the polygon. This code was developed and used by the USGS Mineral Resources Program series of integrated geologic map databases for the United States. This attribute can be used as the join item to other attribute tables provided with the various regional geologic map compilations. Tables for Alaska, Hawaii, Puerto Rico, and the U.S. Virgin Islands datasets do not contain this attribute. The table for Alaska contains an NSA_CLASS item. NSA_CLASS is a numeric code used as the common link item for data tables used in geologic map compilations for the State of Alaska by the USGS.

$U R L$

This is a link to source geologic data that allows the user to view State-level descriptive information about the lithostratigraphic unit, and the sources used to compile these data. For carbonate areas in the contiguous United States, this is a URL that links to the USGS Minerals Online Spatial Data page containing a brief description of the lithostratigraphic unit and other links to State and other geologic information. These addresses were checked and found to be current in June 2014. The URL item in the data tables for Alaska and Hawaii contains an item labeled "URL," with links to source data for individual areas of the State compilation. The URL item for Puerto Rico links to the source publication for the karst extent. The URL item for the U.S. Virgin Islands links to the source geologic report.

\section{NA_L3NAME}

This is the North American Level III Ecoregion name for the ecoregion in which the polygon is located. The potentially karstic polygon areas in soluble rocks in Alaska and the contiguous United States are split at these ecoregion boundaries. The shapefiles for Hawaii, Puerto Rico, and the U.S. Virgin Islands do not include this attribute because they lie outside of the classification area.

\section{NA_L3CODE}

This is a standard North American Level III Ecoregion code for the ecoregion in which the polygon is located. The shapefiles for Hawaii, Puerto Rico, and the U.S. Virgin Islands do not include this attribute because they lie outside of the classification area.

\section{COMMENTS}

This is a text field for miscellaneous comments on the particular lithostratigraphic unit or polygon. Most of these values are empty in this version of the data. 


\section{Areas of karst in quartz sandstone}

A single shapefile contains data delineating a documented area of karst solution features in Minnesota (Shade, 2002). The structure of the data table for this shapefile is identical to that of the previously described table for carbonate rocks in the contiguous United States.

Areas of outcropping evaporite rocks

There is one shapefile containing data for the distribution of exposed or thinly covered evaporite rocks in the United States. The geographic extent of these data is limited to the contiguous 48 States. The structure of the data table for this shapefile is identical to that of the previously described table for carbonate rocks in the contiguous United States except that it does not contain an induration item, because the evaporite deposits are assumed to be well consolidated. The only exception is a single polygon representing unconsolidated surficial deposits of gypsum sand in extensive dunes, located in part within White Sands National Monument in New Mexico.

Areas of sedimentary basins containing thick deposits of evaporite rocks

The data contained in the single shapefile delineating areas of evaporite rocks in subsurface basins has a unique structure and content.

Attributes of the polygons

$B A S I N$

Formal name of the basin or a short description of its location.

FM_NAME

Names of stratigraphic units in the basin that contain evaporite rocks.

FM_AGE

Ages of evaporite rocks within the basin.

FM_DEPTH

Approximate depth or depth range of the evaporite rocks below land surface, in meters.

\section{THICKNESS}

Approximate thickness or thickness range of the evaporite-bearing strata.

\section{LITHOLOGY}

Predominant type of evaporite rock found in the strata. 
Area of greater extent of commonly occurring evaporite rocks in the subsurface

This shapefile contains one polygon delineating the greater extent of commonly occurring subsurface evaporite rocks, predominantly gypsum and anhydrite, outside of the major evaporite basins. There are no attributes other than geometry.

Areas of volcanic pseudokarstic rocks

Three shapefiles are provided for delineating the extent of potentially pseudokarstic volcanic rock (vulcanokarst) areas of the United States. They are (1) volcanic flow rocks in the contiguous United States, (2) volcanic flow rocks in Alaska, and (3) volcanic flow rocks in Hawaii.

Attributes of the polygons

The shapefile providing information on the distribution of potentially pseudokarstic volcanic rocks in the contiguous United States contains the same items using the same table structure as that described for the carbonate rocks, except that it does not contain the two ecoregion items, NA_L3NAME and NA_L3CODE.

The shapefile providing information on volcanic flow rocks in Alaska shares similar data structure as the shapefile describing carbonate rocks from Alaska, except that it does not contain the two ecoregion items (NA_L3NAME and NA_L3CODE) and it uniquely contains AGE_MIN_MA and AGE_MAX_MA. These items contain numeric values for the minimum and maximum ages of the volcanic flow in mega-annum (Ma).

The shapefile providing information on volcanic flow rocks in Hawaii was derived from data in Sherrod and others (2007). The data table includes the following items:

KARST_TYPE

Presently contains only one text string, "Volcanic rocks with potential for pseudokarst features." ROCKTYPE

Short text description of extrusive igneous rock type.

\section{LITHOLOGY}

Short note on lava type or mineralogy.

UNIT_SYMB

Map symbol used for the unit on the source map.

UNIT_NAME

Lithostratigraphic unit name.

SUBUNIT

Individual subunit or flow name. 
AGE_RANGE

Estimated age, or range in age, in years or dates.

$U R L$

URL link to source-map data.

COMMENTS

Miscellaneous comments on the map unit or polygon.

Areas of sedimentary pseudokarstic rocks, including areas prone to thermokarst in Alaska

Two shapefiles are provided for areas of potentially pseudokarstic sedimentary rocks in the United States. They are (1) areas having potential for pseudokarst in sedimentary deposits in the contiguous United States and (2) areas having potential for thermokarst in permafrost regions in Alaska.

Attributes of the polygons

The shapefile providing information on the distribution of areas with potential for pseudokarst in sedimentary deposits in the contiguous United States contains the same items using the same table structure as that described for the carbonate rocks, except that it does not contain the two ecoregion items, NA_L3NAME and NA_L3CODE.

The layer depicting the extent of actual and potential thermokarst development in Alaska was derived from the intersection of two spatial datasets: (1) the spatial coverage of Quaternary surficial deposits in Alaska and (2) the spatial coverage of permafrost in Alaska. The data for the Quaternary geological coverage were obtained from the source given above (Reed and Bush, 2005), and were determined to be of adequate resolution $(1: 7,500,000$ scale) in order to depict the general distribution of Quaternary sediments in Alaska. However, the data were not altered so as to be topologically coincident with the geologic polygons obtained from more recent mapping at higher resolution (1:250,000 scale or better). Therefore, minor inconsistencies between the bedrock and surficial coverage do exist. The extent of permafrost was obtained from the Circum-Arctic map of permafrost and ground-ice conditions, Version 2, provided by the National Snow and Ice Data Center (NSIDC) (Brown and others, 2002). A subset of this GIS dataset covering only Alaska was extracted, and from this a second subset of polygons was chosen on the basis of their mapped permafrost characteristics. Only those areas having attributes of continuous or discontinuous permafrost and having significantly thick overburden were retained. The content of ground ice within the overburden being high, medium, or low was an additional data attribute, but was not used as a discriminant in choosing the spatial coverage. Thus, the resulting polygons have combined attributes of permafrost, ground ice condition, and significantly thick overburden.

These permafrost data were not topologically consistent with the two geological spatial datasets, and the extent of permafrost coverage was the least accurate in terms of mapping resolution (1:10,000,000 scale). Therefore, these polygons were intersected and clipped according to the boundaries of the Quaternary surficial deposit polygons, and the resulting polygons were attributed with permafrost coverage according to the polygons obtained from the NSIDC. This process effectively reduced the overall resolution of the permafrost data to that of the NSIDC data, or 1:10,000,000 scale. Caution is advised when viewing and interpreting the data at larger scales. 
The data table includes the following items:

ICE_UNIT

Three-letter unit labels for permafrost polygons from the original source data (Brown and others, 2002). See ICE_TYPE description below for a list of these abbreviations.

ICE_TYPE

General description for ground ice conditions. Corresponding ICE_UNIT abbreviations are shown in parentheses:

Continuous permafrost extent with high ground-ice content in thick surficial deposits (Chf)

Continuous permafrost extent with medium ground-ice content in thick surficial deposits (Cmf)

Continuous permafrost extent with low ground-ice content in thick surficial deposits (Clf)

Discontinuous permafrost extent with medium ground-ice content in thick surficial deposits

(Dmf)

Discontinuous permafrost extent with low ground-ice content in thick surficial deposits (Dlf)

LITHOLOGY

Map-unit label from corresponding area of the geologic map. Currently all polygons occur in "Quaternary rocks."

UNIT_LINK

Code for linking back to source geologic data (Reed and Bush, 2005).

UNIT_AGE

Geologic age of map unit. Currently all polygons are labeled "Quaternary."

NA_L3NAME

located.

This is the North American Level III Ecoregion name for the ecoregion in which the polygon is

NA_L3CODE

This is a standard North American Level III Ecoregion code for the ecoregion in which the polygon is located.

COMMENTS

Field for miscellaneous comments. 


\section{Files for viewing the karst map polygons in Google Earth ${ }^{\mathrm{TM}}$}

The polygon data from this report are also available in compressed KML (.kmz) format suitable for viewing via Google Earth ${ }^{\mathrm{TM}}$ software. Opening these files into Google Earth allows display of the karst and pseudokarst polygons over aerial imagery and terrain models supported by Google Earth. Clicking on individual polygons will pop up the same tabular data as that contained in the GIS files. Because of file size and computer resource limitations, these data are organized differently from the GIS shapefiles. The file names indicate the States or region covered by each.

\section{Conclusions}

About 18 percent of the area of the United States is underlain by soluble rocks having karst or the potential for development of karst features. These areas are further classified into karst map units on the basis of their general climate setting, degree of induration, and depth of burial of the soluble rocks and nature of the overlying sediments. About 3.5 percent of the area of the United States is underlain by sedimentary or volcanic rocks that have potential for the development of pseudokarst features. About 3.6 percent of the area of the United States is underlain by sedimentary deposits in permafrost conditions with potential for development of thermokarst features. These karst and pseudokarst areas are graphically portrayed in the figures included with this report, and are also represented in a GIS database as polygon features.

\section{References Cited}

Alemán González, W.B., comp., 2010, Karst map of Puerto Rico: U.S. Geological Survey Open-File Report 2010-1104, 1 sheet, scale 1:140,000, accessed April 17, 2014, at http://pubs.usgs.gov/of/2010/1104.

Auler, A.S., and Smart, P.L., 2003, The influence of bedrock-derived acidity in the development of surface and underground karst; evidence from the Precambrian carbonates of semi-arid northeastern Brazil: Earth Surface Processes and Landforms, v. 28, no. 2, p. 157-168.

Brown, Jerry, Ferrians, O.J., Jr., Heginbottom, J.A., and Melnikov, E.S., 2002, Circum-Arctic map of permafrost and ground-ice conditions, Version 2: Boulder, Colo., National Snow and Ice Data Center, 1 sheet, scale 1:10,000,000.

Daly, Christopher, and Taylor, George, 2000, United States average annual precipitation, 1961-1990: Corvallis, Oreg., Spatial Climate Analysis Service (now PRISM Climate Group of the Northwest Alliance for Computational Science and Engineering), Oregon State University, digital data, accessed June 11, 2014, at http://prism.nacse.org/.

Davies, W.E., Simpson, J.H., Ohlmacher, G.C., Kirk, W.S., and Newton, E.G., 1984, Engineering aspects of karst: U.S. Geological Survey, National Atlas of the United States of America, scale $1: 7,500,000$.

Dunrud, C.R., and Nevins, B.B., 1981, Solution mining and subsidence in evaporite rocks in the United States: U.S. Geological Survey Miscellaneous Investigation Series Map I-1298, 2 sheets, scale $1: 5,000,000$. 
Epstein, J.B., and Johnson, K.S., 2003, The need for a national evaporite-karst map, in Johnson, K.S., and Neal, J.T., eds., Evaporite karst and engineering/environmental problems in the United States: Oklahoma Geological Survey Circular 109, p. 21-30.

Ford, D.C., and Williams, Paul, 2007, Karst hydrogeology and geomorphology: Chichester, United Kingdom, John Wiley \& Sons, 562 p.

Halliday, W.R., 2007, Pseudokarst in the 21st century: Journal of Cave and Karst Studies, v. 69, no. 1, p. 103-113.

Johnson, K.S., 2007, Evaporite-karst problems and studies in the U.S.A.: Environmental Geology, v. 53, no. 5, p. 937-943. doi:10.1007/s00254-007-0716-8.

Klimchouk, A.B., 2007, Hypogene speleogenesis; hydrogeological and morphogenetic perspective: National Cave and Karst Research Institute, Special Paper No. 1, 106 p.

Palmer, A.N., 1991, Origin and morphology of limestone caves: Geological Society of America Bulletin, v. 103, no. 1, p. 1-21.

Palmer, A.N., 2000, Hydrogeologic control of cave patterns, in Klimchouk, A.B., and others, eds., Speleogenesis; evolution of karst aquifers: Huntsville, Ala., National Speleological Society, p. 77-90.

Palmer, A.N., and Palmer, M.V., eds., 2009, Caves and karst of the U.S.A.; a guide to the significant cave and karst areas of the United States of America: Huntsville, Ala., National Speleological Society, $446 \mathrm{p}$.

Palmer, A.N., and Palmer, M.V., 2011, Paleokarst of the U.S.A.; a brief review, in Kuniansky, E.L., ed., U.S. Geological Survey Karst Interest Group Proceedings, Fayetteville, Arkansas, April 26-29, 2011: U.S. Geological Survey Scientific Investigations Report 2011-5031, p. 7-16.

Reed, J.C., Jr., and Bush, C.A., 2005, Generalized geologic map of the United States, Puerto Rico, and the U.S. Virgin Islands: U.S. Geological Survey National Atlas of the United States, accessed April 17, 2014, at http://pubs.usgs.gov/atlas/geologic/.

Shade, B.L., 2002, The genesis and hydrogeology of a sandstone karst in Pine County, Minnesota: Minneapolis, University of Minnesota, M.S. thesis, 131 p., 8 tables.

Sherrod, D.R., Sinton, J.M., Watkins, S.E., and Brunt, K.M., 2007, Geologic map of the State of Hawai i: U.S. Geological Survey Open-File Report 2007-1089, accessed June 5, 2014, at http://pubs.usgs.gov/of/2007/1089/.

Soller, D.R., Packard, P.H., and Garrity, C.P., 2012, Database for U.S. Geological Survey Map I-1970, Map showing the thickness and character of Quaternary sediments in the glaciated United States east of the Rocky Mountains: U.S. Geological Survey Data Series 656, accessed June 5, 2014, at http://pubs.usgs.gov/ds/656/.

Sweeting, M.M., 1973, Karst landforms: New York, Columbia University Press, 362 p.

U.S. Environmental Protection Agency, 2002, A lexicon of cave and karst terminology, with special reference to environmental karst hydrology: Washington, D.C., U.S. Environmental Protection Agency, Office of Research and Development, National Center for Environmental Assessment, EPA/600/R-02/003, 214 p.

U.S. Environmental Protection Agency, 2013, Level III and IV Ecoregions of the continental United States: Office of Research and Development (ORD) - National Health and Environmental Effects Research Laboratory (NHEERL), accessed June 19, 2014, at http://www.epa.gov/wed/pages/ecoregions/level_iii_iv.htm\#Level III. 
U.S. Geological Survey, 2013, Geologic maps of U.S. States: U.S. Geological Survey, Mineral Resources Program, Mineral Resources Online Spatial Data, accessed August 8, 2013, at http://mrdata.usgs.gov/geology/state/.

Veni, George, 2002, Revising the karst map of the United States: Journal of Cave and Karst Studies, v. 64, no. 1, p. 45-50.

Williams, P.W., and Ford, D.C., 2006, Global distribution of carbonate rocks: Zeitschrift für Geomorphologie, Supplementband, v. 147, p. 1-2. 